\title{
The original Operation Twist: the War Finance Corporation's war bond purchases, I9I 8-I920
}

\author{
JAMES L. BUTKIEWICZ and MIHAELA SOLCAN \\ University of Delaware
}

In I9I 8 the United States Treasury delegated to the War Finance Corporation, a newly created offbudget federal agency, the task of buying Liberty bonds and later Victory notes in an effort to stabilize prices. Bayesian vector autoregression analysis of the security purchases indicates that the WFC purchases provided statistically significant price support, and marginally lowered bond yields while the program operated. Once WFC purchases ended, war bond yields increased substantially. Between bond issues, the Treasury financed its operations, including security purchases from the WFC, by issuing shortterm debt, which affected the money market interest rate. The WFC's bond purchases are found to have a positive and significant impact on the call loan rate. Thus the WFC's bond purchases twisted the yield curve.

Keywords: War Finance Corporation, US war bonds, yield curve, Bayesian structural vector autoregression

JEL classification: $\mathrm{N}_{22}, \mathrm{~N}_{42}$

Recent rounds of quantitative easing by the Federal Reserve and other central banks have generated interest in the efficacy of policies attempting to affect the yield curve. The goal of quantitative easing is to reduce long-term interest rates through purchases of long-term bonds. This attempt to flatten the yield curve is intended to stimulate economic activity.

J. L. Butkiewicz (corresponding author), University of Delaware, Department of Economics, Newark, DE I9716, USA; email: jimb@udel.edu. M. Solcan, Deloitte Economic Consulting, London; email: solcanm@gmail.com. This article extends chapter 3 of Solcan's doctoral dissertation written at the University of Delaware. The authors acknowledge the helpful comments of Burton Abrams, Samuel Allen, Stacie Beck, Farley Grubb, Siyan Wang, Mark Wohar and especially two anonymous referees whom we thank for their many helpful comments and suggestions. Responsibility for any errors rests with the authors. 
Expectations-based theories of the term structure of interest rates deny the ability of bond purchases to change the yield curve. Even if wealth holders have preferences for specific bond maturities, arbitrage eliminates the effect on yields from changes in supply.

Vayanos and Vila (2009) have developed a preferred habitat model of the term structure with risk-averse arbitrageurs, where shocks to demand will change the shape of the yield curve. They cite as supporting evidence the US Treasury's bond buy-back program of 2000-2 as reducing the yield on 30-year bonds by 58 basis points within three weeks of the program's announcement.

An earlier attempt to flatten the yield curve was Operation Twist that began in I96I. The original studies by Modigliani and Sutch (I966, I967) find a slight to moderate impact of the program on the yield curve, but the effect on the longest maturities was insignificant. A recent study by Swanson (2OI I) finds that the program's impact on long-term Treasury yields was statistically significant, but of modest size, about I 5 basis points. This is consistent with the range of IO-2O basis points found by Modigliani and Sutch.

D'Amico et al. (2012) find that the Fed's first round of asset purchases in 2009 reduced the Io-year Treasury yield by 35 basis points while the 20IO-II program reduced the Io-year yield by 45 basis points. Gagnon et al. (20 I I) report a decrease in the IO-year yield of 9I basis points in response to the first round of asset purchases.

All of these studies find that programs of bond purchases affected the yield curve. Another little-known and previously unstudied program of bond purchases was conducted by the War Finance Corporation (WFC) from mid-I9i 8 through early I920. The WFC was a federal agency wholly owned by the US Treasury. The bond-buying program involved purchases of longer-term war bonds and notes. The WFC sold these securities to the Treasury for the average price paid plus interest. Between Liberty and Victory Loan security issues, the Treasury financed its spending net of taxes by issuing short-term Certificates of Indebtedness. As discussed below, the WFC security purchases required that the Treasury issue other debt when it repurchased securities from the WFC. Thus, the WFC's security purchase program implied swapping maturities between Liberty Loan sales.

This article uses original archival data and other original series to investigate the impact of the WFC purchases of war bonds, in order to assess whether the purchases stabilized bond prices, and also to assess the impact of purchases on the yield curve. The next section recounts the rationale for the creation of the War Finance Corporation. Section III provides a detailed description of the war security issues. Section IV discusses the Treasury's financing requirements and activities. The model, Bayesian Structural Vector Autoregression (BSVAR), is presented in Section V. Section VI describes the data used in the analysis. The findings are reported in Section VII. Section VIII concludes the article and the appendices present the empirical methodology in detail and the results of a robustness test. 
The US federal government was almost debt free prior to World War I. In December I9I6, gross federal debt was 2.67 percent of GNP. ${ }^{1}$ In order to finance the war efforts of the European Allies and of the United States, the US Treasury issued five war loans between June I9I7 and May I920. The four issues during the hostilities were Liberty Loans (LL) and the final issue following the war was the Victory Loan (VL). By December I9I9, gross debt peaked at 33.46 percent of GNP.

Marketing of the war loans emphasized the patriotic duty of citizens to buy bonds, and bonds were issued in small as well as large denominations to facilitate purchases by individuals with little financial wealth. ${ }^{2}$ Although the bond issues were a success, ${ }^{3}$ the market prices of both the Liberty bonds and Victory notes decreased shortly after they were issued. As the Treasury had aggressively marketed the bonds to the public, the ensuing price depreciation engendered considerable discontent.

When the federal government began borrowing heavily to finance the war effort, Treasury Secretary William McAdoo worried about the availability of funds for businesses essential to the war effort. In January i9 8 McAdoo formed a Capital Issues Committee comprised of three members of the Federal Reserve Board. ${ }^{4}$ The committee passed on proposed security issues, advising against those that it found to be unnecessary during the war. However, the committee's recommendations were advisory and not compulsory. McAdoo desired formal authority for the committee with the ability to penalize unnecessary security issues.

In I9I 8 McAdoo proposed legislation creating a War Finance Corporation. The WFC legislation, passed on 5 April I9I 8 , had two primary objectives: formalizing the Capital Issues Committee and providing financing for businesses deemed essential to the war effort. ${ }^{5}$ In conjunction with the war financing provision, the WFC was also authorized to trade and deal in federal debt securities. The WFC was created as an offbudget agency. The Treasury provided capital of $\$ 500$ million, and the WFC was authorized to sell an additional $\$ 3$ billion of bonds as needed to fund its lending.

The WFC bill as passed created a formal Capital Issues Committee with seven members, but its recommendations remained advisory. The ability to penalize security issues that were deemed unnecessary to the war effort was removed from the final legislation.

The second provision of the legislation authorized the WFC to provide funding to essential industries otherwise unable to obtain financing. As the war ended in

1 Federal debt data is from Board of Governors of the Federal Reserve System (I943). GNP data is from Balke and Gordon (I989).

2 Kang and Rockoff (2015) investigate the impact of patriotism on war bond yields.

3 The amount subscribed always exceeded the amount issued for all the five loans (Gilbert I970).

4 Willoughby (I934) provides a detailed account of the Capital Issues Committee and the War Finance Corporation.

5 Subsequent legislation authorized the WFC to provide funding for exports and to lend to banks and agricultural financing agencies during the agricultural crisis of I92 I-3. 
Table I. War Finance Corporation purchases of Liberty bonds and Victory notes, 1918-20 (\$ million)

\begin{tabular}{|c|c|c|c|c|c|c|c|c|}
\hline & $\begin{array}{l}\text { First Liberty } \\
\text { bond } 4 \%\end{array}$ & $\begin{array}{l}\text { First Liberty } \\
\text { bond } 4.25 \%\end{array}$ & $\begin{array}{l}\text { Second Liberty } \\
\text { bond } 4 \%\end{array}$ & $\begin{array}{l}\text { Third Liberty } \\
\text { bond } 4.25 \%\end{array}$ & $\begin{array}{c}\text { Fourth Liberty } \\
\text { bond } 4.25 \%\end{array}$ & $\begin{array}{c}\text { Victory } \\
\text { bond } 3.75 \%\end{array}$ & $\begin{array}{c}\text { Victory } \\
\text { bond } 4.25 \%\end{array}$ & Total \\
\hline I9I 8 & I. 2 & 3.4 & 27.7 & 202.3 & 92.8 & 0.0 & 0.0 & 327.4 \\
\hline I9I9 & I 5.8 & I0.2 & 59.8 & 278.3 & 388.2 & $4 \mathrm{I} \cdot 7$ & I 26.0 & 919.9 \\
\hline I920 & $3 \cdot 7$ & $3 \cdot 3$ & 8.2 & $45 \cdot \mathrm{I}$ & 65.4 & 47.9 & 40.3 & 213.8 \\
\hline Total & 20.7 & I6.9 & 95.6 & $525 \cdot 7$ & 546.4 & 89.6 & I66.3 & $\mathrm{I}, 46 \mathrm{I} .2$ \\
\hline $\begin{array}{l}\text { Percentage of total } \\
\text { WFC Purchases }\end{array}$ & I. $4 \%$ & I.2\% & $6.5 \%$ & $36.0 \%$ & $37.4 \%$ & $6.1 \%$ & II. $4 \%$ & \\
\hline
\end{tabular}

Note: WFC also purchased converted Second Liberty bonds, not reported here.

Source: National Archives Record Association II. Record Group I 54 . 
November I9I 8, the WFC lending to finance essential industries totaled only \$30I.5 million, of which $\$ 204.8$ million were I9I9 loans to railroads to assist the United States Railroad Administration with the federal operation of the railroads. ${ }^{6}$ The WFC's wartime lending was limited.

The WFC was also authorized to deal in federal debt securities. Eugene Meyer, an original WFC director and later managing director, was responsible for the bond purchases. Meyer (1974, box I80) recalled that McAdoo wanted to stabilize the market for war bonds to avoid a rate increase on the third Liberty Bond. In the two-year period that it purchased war bonds to support prices, the WFC purchased \$I,46I million of bonds at market prices. ${ }^{7}$ These purchases totaled 7.I percent of the par value of $\$ 20.5$ of war securities sold, or 7.5 percent of market value assuming an average price of $\$ 0.95$ per $\$$ I of par value.

The war placed tremendous financial burdens on the federal government. Federal expenditures increased from $\$ 734$ million in fiscal year I9I6 to $\$$ I 8,5 I5 million in fiscal year I9I $8 .{ }^{8}$ Correspondingly, income tax rates and total tax revenue both increased dramatically. Income tax revenue was \$I25 million in fiscal year I9I6 and peaked at $\$ 3,945$ million in fiscal year I920. Total receipts also peaked in fiscal year I920 at $\$ 6,695$ million. Still, the majority of the increased spending was debt financed. The increases in gross debt totaled $\$ 24,259$ million for fiscal years I9I7-I9.

The Treasury sold five security issues (four Liberty Loans and one Victory Liberty note) between June I9I7 and May I919. ${ }^{9}$ Between issues the Treasury sold shortterm Certificates of Indebtedness to obtain temporary funding in anticipation of the war bond issues. Some certificates were also sold to be used for payment of income and profits taxes. ${ }^{10}$

The First Liberty Loan Act, passed on 24 April I9I7, authorized the Treasury to issue $\$ 5$ billion worth of bonds at a rate less than or equal to 3.5 percent interest. ${ }^{11}$ The Treasury issued $\$ 2$ billion of bonds on I4 May I9I7, that were to mature in I947. The denominations ranged from as low as $\$ 50$ to over $\$ 250$,000 and it was

6 Details of all WFC operations are summarized in Secretary of the Treasury (I943).

7 This sum is obtained from War Finance Corporation (box I I 4, vol. 3 I). Purchases of converted Second Liberty Bonds are not included, as these purchases were too infrequent for time-series analysis. The Secretary of the Treasury (I943) reports that the WFC purchased a total par value of \$I,9I2 million of bonds at a total cost of \$I,8I8 million. The WFC did make occasional purchases for the Treasury after the price support program ended (Secretary of the Treasury I943, p. I2).

8 All data in this paragraph are from Board of Governors of the Federal Reserve System (I943).

9 The maturity of the Liberty Loan bonds ranged from ro to 30 years, while the Victory Loan bonds had a shorter four-year maturity.

10 The use of certificates of indebtedness is explained by the Secretary of the Treasury (I9I9).

11 The details of the chronology of bond issues and financial terms for each loan is based on Gilbert (I970) and the Commercial and Financial Chronicle, weekly issues. 
oversubscribed by 52 percent (Gilbert 1970). The main attraction of the First Liberty bond was probably its favorable income tax exemption, as the top marginal income tax rate in I9I 7 was 67 percent. ${ }^{12}$

The First Liberty bonds were convertible into subsequent issues bearing higher coupon rates. Conversions resulted in separate stock exchange listings of First Liberty Loans at 4 percent and also at 4.25 percent. ${ }^{13}$

The Second Liberty Loan Act, passed by Congress on 24 September I9I 7, authorized the Treasury to issue more than $\$ 7.5$ billion of bonds maturing in 1942 at a 4 percent interest rate. Although the Second LL did not carry the tax-exemption privileges of the First Liberty bond, its final subscription still surpassed the total allotment by 54 percent (Gilbert I970).

By the spring of I9 8 , all the Liberty bonds were selling below par. For instance, at the beginning of March I9I 8, the First Liberty bond at 3.5 percent was selling at 97.86 (and 97.08 for the First LL at 4 percent), ${ }^{14}$ while the Second Liberty bond was selling at 96.34 . Both the Treasury and Congress were concerned by this decline in prices, as the Treasury was preparing to issue the Third LL. On 9 May I9I 8, the Treasury issued $\$ 3$ billion of Third LL bonds at 4.25 percent, maturing in I928. From the start, Third LL bonds were selling below par. The average price during the first trading week (Commercial and Financial Chronicle) was 98.4. In I9I 8 the Treasury was drowning in deficits. Gilbert (I970) reports that for July I9I8, the Treasury registered a deficit of over \$I billion.

On 24 October I9I 8, \$6 billion of the Fourth Liberty bonds were issued at 4.25 percent, maturing in 1938 . In order to maintain its price at par, the Fourth Liberty bond included the tax-exempt provision. However, by the end of December I9i 8 , it was selling below par at 94 .

In a final attempt to raise government bond prices, the Victory Liberty note was issued on 2 I April I9I9, at 3.75 and 4.75 percent, maturing in I922-3. Just as for the Fourth Liberty bond, the Victory Liberty note included the important taxexemption provisions on the income resulting from holding old Liberty bonds, for any amount not higher than $\$ 20$,000 (Gilbert I970).

Because Liberty bonds were trading at a discount during the winter of I9I7-I 8, the Third Liberty Bond Act, passed on 4 April i9 8 , authorized the Treasury to purchase up to 5 percent annually of the outstanding amount of each war bond series, ${ }^{15}$ except

12 The first Loan was exempt from all income taxes, and subject only to estate and inheritance taxes (Gilbert I970, p. I22).

13 'Topics in Wall Street: six Liberty Loan issues', New York Times, I4 July I9I 8, p. 28. The WFC purchased small amounts of the First LLs at 4 and $4.25 \%$, as discussed below. Gilbert (I970) discusses the conversion of Liberty Loans.

14 The tax exemptions offered by the First LL at $3.5 \%$ were more favorable than both subsequent LL issues or converted First issues, which is most likely why the $3.5 \%$ issue did not trade at a larger discount.

15 Section I 5 of the Second Liberty Bond Act, as added by section 6 of the Third Liberty Bond Act of 4 April I9I 8 authorized the bond purchases. The Act is reproduced in Secretary of the Treasury (I9I9). 


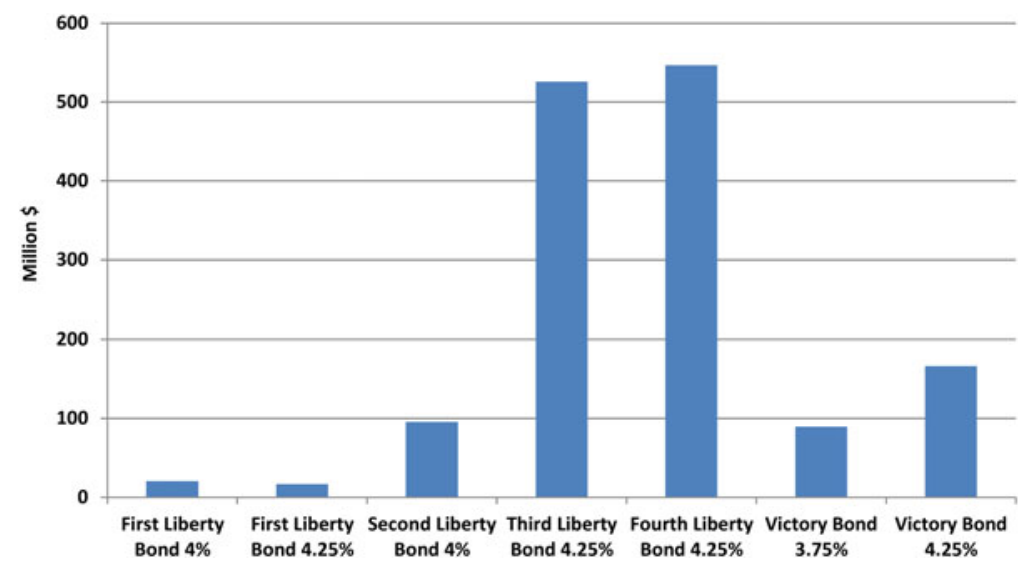

Figure I. WFC purchases of Liberty bonds and Victory notes (\$millions) Source: National Archives Record Association II. Record Group I 54.

the First Liberty bond at 3.5 percent (Gilbert 1970). The initial tax-exemption provision of the First bond was probably the main driver behind its relatively higher prices (although still not at par) during the Liberty and Victory Loan Campaigns.

The Treasury delegated the bond purchases to the newly formed WFC. The WFC initiated operations in May I9I 8 and made its first bond purchases in June of the same year. WFC purchases of the various issues are depicted in Figure I. Meyer's policy was to prevent war bond prices from falling more than a quarter of a point in a day, regardless of the amount traded. ${ }^{16}$ The WFC purchased war bonds and sold them to the Treasury at the average price paid plus interest.

\section{IV}

The Third Liberty Bond Act authorized the Treasury to set aside unappropriated funds to pay for the bond purchases. This provision proved to be ineffective in reducing aggregate federal debt, as discussed when the original sinking fund ${ }^{17}$ was replaced by a new fund created in conjunction with the Victory Loan legislation, as explained in the I9I9 Annual Report of the Secretary of the Treasury:

The [Victory Liberty Loan] act of March 3, I9I9, also repealed the old sinking-fund statutes which had proved unworkable and resulted in nothing more or less than a bookkeeping account. They did not retire the debt. The new law which takes the place of the provisions

16 Meyer's policy is discussed by Pusey (I974).

17 As indicated in the quote below, due to the wartime deficits, no revenues were available to allocate to a sinking fund for debt retirement. 
thus repealed can never descend to the state of uselessness which they occupied as long as the Government keeps faith with investors in its obligations ... To make the plan effective, sinking-fund charges must be met out of revenues received from taxation. Any thought in the future of suspending operations of the cumulative sinking fund or of meeting its charges through the sale of securities would not only be unwise in the extreme ... but would be a breach of faith with every subscriber to the Victory Liberty loan and with every holder of Liberty bonds. Whatever may be necessary in the future financing of the Government, nothing must be permitted to interfere with the effective operation of the cumulative sinking fund and the consequent gradual retirement of the war debt. (Secretary of the Treasury, I920b, $85-6$ )

Once the WFC began buying war securities in an effort to stabilize price, its purchases occurred regularly. The WFC had initial capital of $\$ 500$ million. Its lending to industries totaled \$30I.5 million, of which \$200 million was financed by the WFC's only bond issue. Thus, the WFC had considerable operating capital with which to purchase securities and carry an inventory. It would periodically sell part of its inventory of war securities to the Treasury at the average price paid plus accrued interest. ${ }^{18}$ The record of Treasury purchases is reported in Secretary of Treasury (I920a). The timing of the WFC purchases of war securities is not highly correlated with sales of these securities to the Treasury (correlation coefficient .I7).

The WFC's bond purchases were to be financed by subsequent bond issues. However, the Treasury regularly sold certificates of indebtedness between war security sales in anticipation of these security issues. The sales of certificates between Victory and Liberty Loan security issues were sizable. It was reported that 'the proceeds of the Fourth Liberty Loan in excess of the amount of Treasury certificates issued in anticipation of that loan has been exhausted'. ${ }^{19}$ It was also reported that 'the certificates alternate inflate and contract the money market in a manner that remains regrettable'. ${ }^{20}$

Treasury certificates of indebtedness were issued regularly, often at two-week intervals, to finance all government spending, including Treasury repurchases of war securities from the WFC. The financing of bond purchases with sales of shortterm debt and the effect on interest rates was emphasized by Assistant Treasury Secretary Leffingwell in his I6 April I920 letter to Meyer directing the WFC to cease bond purchases:

The Treasury has been obliged to resume the issue of loan certificates and at increasing rates of interest. Under these circumstances, purchases of long-term obligations out of the proceeds of the sale of Treasury certificates will only add to the Treasury's difficulties and consequently

18 The Treasury reported (Secretary of the Treasury I920a, p. 82): 'The bonds have been purchased by the corporation [WFC] at the market price for its own account, and subsequently the accumulated stocks have been taken over by the Treasury at the average cost to the corporation, plus accrued interest.'

19 'McAdoo problems left to Mr Glass', New York Times, is December i9 1 8, p. 46.

20 'The Treasury's year', New York Times, 6 July I920, p. Io. 
cannot in the long run benefit the holders of bonds and notes or strengthen the market price of bonds and notes. (Leffingwell I96I, reel 35) (1) $^{21}$

Treasury Secretary McAdoo noted that the bond purchases required issues of shortterm debt: 'By discontinuing purchases of Liberty Bonds for retirement under provisions of the existing law, the Treasury would be relieved of a large burden now reflected in the floating debt...'22

In essence, the WFC bought war bonds to stabilize their prices. The bonds were resold to the Treasury, but due to the sizable deficits, the Treasury sold other short-term debt, Certificates of Indebtedness, to pay for the retired war bonds. While the timing between the WFC security purchases and sales of Treasury certificates cannot be clearly established, it is possible that WFC security purchases affected the money market either directly or indirectly through an expectations effect.

Federal finances had improved from a $\$$ I 3,363 million deficit in fiscal year I9I9 to a \$29I million surplus in fiscal year I920 (Board of Governors of the Federal Reserve System I943). Thus, the WFC security purchases had occurred during a period of sizable deficits followed by a small surplus. For the most part, WFC security purchases did not reduce the debt, but merely retired long-term debt funded by short-term debt. While unintentional, this was the original Operation Twist, a precursor of the Federal Reserve's policies of I96I and 20I I-I2.

This study investigates two questions. Did WFC security purchases stabilize bond prices, avoiding further depreciation, or even increasing war security prices? Secondly, did WFC security purchases, funded by sales of short-term debt, increase short-term interest rates?

The WFC war security purchases were made during a period of rising inflation and potentially increased risk. The rate of inflation as measured by the CPI increased from I percent in I9I 4 and I9I 5 to the mid- to high-teens during the years I9I 7-20, before the post-war deflation. ${ }^{23}$ Uncertainty from the war and rapid debt growth may have increased the perceived risk for war securities. An increasing risk premium would increase security yields. Both factors would be expected to put upward pressure on nominal yields, lowering security prices. ${ }^{24}$

Another factor increasing yields were the increases in Federal Reserve discount rates that began in November I9I9. The New York Federal Reserve's discount rate for commercial paper with maturities of I 5 days or less was set at 4 percent in April I9I8 and held constant through early November igi9 (Board of Governors

21 Pusey (I974) also recounts that Leffingwell felt too much money was spent on war bond purchases, and that he wanted to stop selling short-term debt at higher rates to fund the bond purchases.

22 'Tax cut of billions urged by McAdoo to help business', New York Times, 5 March I920, p. I.

23 Inflation rates are computed using the Bureau of Labor Statistics CPI data.

24 While nominal rates increased during the war years, the increase was small relative to the increase in inflation. For long-term bonds, expectations of an end to war-time inflation and the fact that the bonds contained a gold clause (payable in gold) kept yields on these bonds low, but this does not explain the small increase in short-term yields relative to inflation (Meltzer 2003, pp. 88-9). 
I943, p. 439). The discount rate was increased to 4.75 percent in November, 6 percent in January 1920 and 7 percent in June 1920. The upward trend in war bond yields is evident in Figures 2 and 3 below. The econometric models include the New York Fed's discount rate as a control for this trend in interest rates.

Prima facie support that the WFC purchases did stabilize prices is provided in Figures 2 and 3, for the Third and Fourth LL. ${ }^{25}$ Upon receiving the directive to cease buying, Meyer discontinued most security purchases after the week of 19-23 April I920, although he was given a deadline of 30 June 1920 to end the purchases. ${ }^{26}$ The vertical line in each figure indicates the date of the announced end of WFC purchases ${ }^{27}$ and the corresponding change in war security yields. It is evident that the yield increases preceded the end of the purchases. Yields increased when the announcement was made, a week in advance of the actual termination of purchases. The announcement of the termination of the purchase program most likely changed expectations regarding future war security yields at the time of the announcement:

Hereafter such purchases as the Treasury may have to make for the bond purchase fund of the sinking fund under the general program above announced will be occasional and not habitual. (New York Times, is April I920, p. I 5)

While the data in the figures suggest that WFC purchases stabilized prices, the impact of WFC purchases on war security yields will be investigated econometrically.

For each war security, a four-equation Bayesian Structural Vector Autoregression (BSVAR) model that includes the following endogenous variables is constructed: ${ }^{28}$ the call loan rate (CLR) as the short-term market interest rate, the New York Federal Reserve's discount rate (NY) as the primary monetary policy tool, Liberty security yields (WBY), and WFC security purchases of each specific security issue (WFC). The war security yields to maturity are computed using the price data for Liberty securities. ${ }^{29}$ WFC purchases are expressed in millions of US dollars.

Table 2 lists the non-recursive restrictions on the contemporaneous matrix $A_{o}$. Zero restrictions imply the lack of contemporaneous responses. The call loan rate restrictions assume the Fed responds to changing rates (market conditions) by changing its discount rate. Call loan rate shocks affect war security yields through the term structure. Changes in the discount rate affect the call loan rate during the

25 Figures for the other issues, all displaying similar behavior of yields, are available from the authors.

26 For the week of I9-23 April, purchases of the third issue fell to a mere $\$ 262,000$, while purchases of the fourth issue were $\$ 922,000$ that week. There were additional purchases of the First and Fourth Liberty Bonds in May and June I920.

27 The announcement is cited immediately below.

28 Appendix I presents the technical details in constructing the BSVAR models.

29 The yields to maturity are obtained by using the following formula: Yield $=[\mathrm{C}+((\mathrm{F}-\mathrm{P}) / \mathrm{n})] /[(\mathrm{F}+\mathrm{P}) / \mathrm{n}]$ where $\mathrm{C}$ is the coupon rate on war bonds, $\mathrm{F}$ is par value, $\mathrm{P}$ is price and $\mathrm{n}$ is time to maturity. 


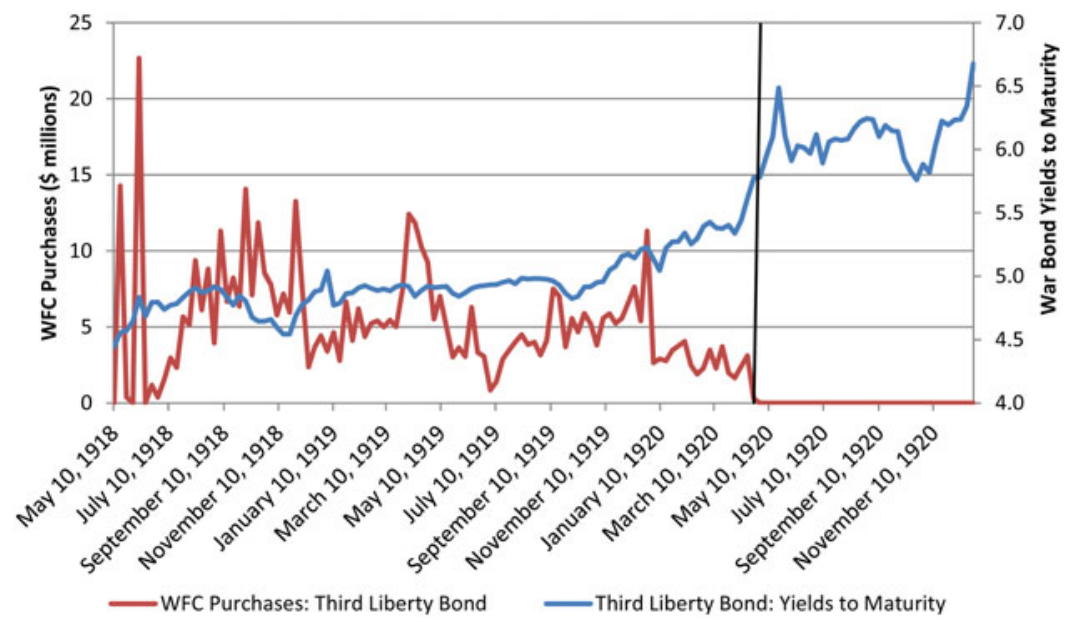

Figure 2. Third Liberty bond at 4.25 percent: yields to maturity and WFC purchases Note: WFC purchases of the Third LL contain April and May I9I 8 purchases carried out by New York Federal Reserve.

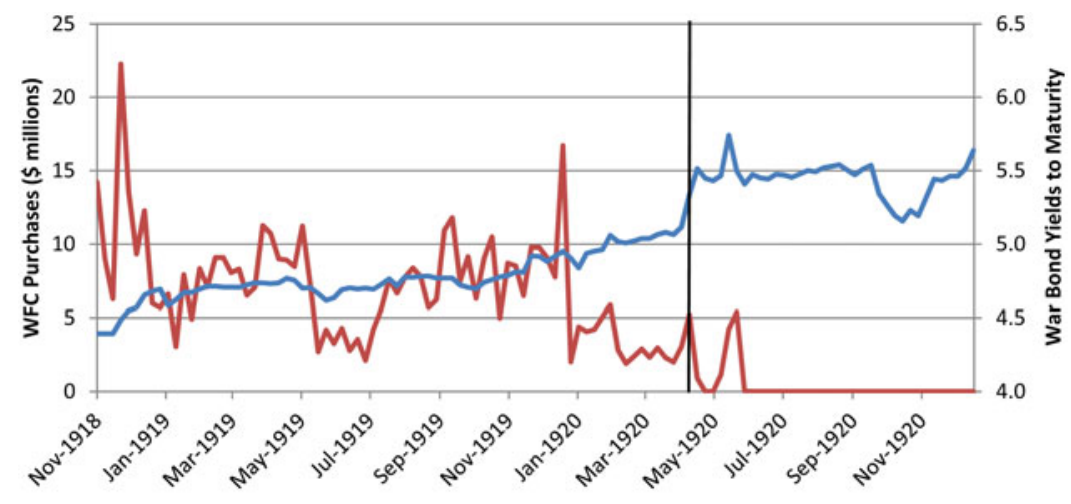

WFC Purchases: Fourth Liberty Bond _ _ Fourth Liberty Bond: Yields to Maturity

Figure 3. Fourth Liberty bond at 4.25 percent: yields to maturity and WFC purchases

same week. It is further assumed that WFC purchases do not respond within a week to changes in New York Fed's discount rate or the call loan rate, while the call loan rate is assumed not to be affected by changes in war security yields in the same week. The WFC responds to changes in war security yields, and WFC purchases affect both short-term and long-term interest rates. 
Table 2. The structure of the non-recursive contemporaneous matrix $\left(A_{0}\right)$

\begin{tabular}{lcccc}
\hline \hline Variables & CLR & NY & WBY & WFC \\
\hline CLR & $\star$ & $\star$ & 0 & $\star$ \\
NY & $\star$ & $\star$ & 0 & $\star$ \\
WBY & $\star$ & 0 & $\star$ & $\star$ \\
WFC & 0 & 0 & $\star$ \\
\hline \hline
\end{tabular}

Note: The cells marked with * represent the contemporaneous relationships ('free' parameters) to be estimated, while the cells recording o represent zero restrictions.

The data set is constructed at weekly frequency, covering the period November I9I7 through December I920. This sample period includes the entire period of WFC bond purchases, and also includes intervals with no WFC bond purchases at both the beginning (for some issues) and end of the sample. ${ }^{30}$

The unique feature of the data set used for this study is the collection of original WFC security purchase data. The purchase data is collected from the WFC's Register on Purchases, Sales, Holdings, and Conversions of Liberty Loan Bonds, I9I8-22, at the National Archives and Records Association II (Record Group I 54, box I I4, vol. 3I). The data for WFC purchases covers the June I9I 8 - June I920 period. Treasury records indicate that purchases of Third Liberty Loan bonds were made during April and May i9i 8, prior to the WFC's purchase program (Secretary of the Treasury, 7 December, I920a). As indicated in the Treasury letter (p. I), these purchases were made through the Federal Reserve Bank of New York. As these purchases were intended to stabilize prices, we include the April-May I9I 8 purchases in our data for WFC purchases of the Third Liberty Loan bonds. ${ }^{31}$ All purchase data is at market prices.

A second original data series is for weekly call $\operatorname{loan}^{32}$ rates that are computed as averages of the daily high and low rates. ${ }^{33}$ The call loan rate better displays money market conditions than the commercial paper rate. While the commercial paper

30 Estimates begin in December I9I 7 for the First Liberty bond at $4 \%$ and the Second Liberty bond. For other issues, estimates begin at dates when the loans were marketed. For the First bond at $4.25 \%$ and the Fourth, WFC purchases began when the bonds were first sold, so there is no interval of zero purchases at the beginning of the sample for these two issues.

31 Given the daily frequency of these purchases, we assumed that the New York Fed purchased the bonds and immediately sold them to the Treasury

32 Call loans were loans financing security purchases.

33 Monday issues of the New York Times published tables listing the daily call loan rates from the previous week. The high-low average corresponds most closely to the weekly call loan series published in Board of Governors of the Federal Reserve System (I943, p. 452). The Board data begins only in 
rate follows an upward trend, there is very little weekly variability, due to the ability to discount commercial paper with the Fed. Bankers' acceptances could be sold to the Fed at the bill-buying rate. Thus, Fed policies anchored these rates. This was not true for call loans, since lending for security purchases violated the Fed's 'real bills' philosophy. For example, in November and December i919, call loan rates exhibited considerable variability, due to high credit demand in November and a declining Federal Reserve System reserve ratio in December. ${ }^{34}$ The weekly call loan rate much better reflects money market tightness than the commercial paper rate. ${ }^{35}$

A third original data series is for Liberty and Victory security prices that are obtained from the Commercial and Financial Chronicle (weekly issues, I9I7-I92I). For comparability with the interest rates used in the BSVAR models, yields to maturity are used instead of security prices. WFC purchases are measured in millions of dollars to obtain the same scale for all the variables in the BSVAR models. The New York Fed's weekly discount rates are computed from data available in Board of Governors of the Federal Reserve System (I943).

As depicted in Figures 2 and 3 above, WFC price stabilization efforts required increased purchases at the end of I9I9. The models for the Third and Fourth LL include a control variable to account for the defeat of the Central Powers that might have affected war security yields during the WFC purchasing program. The dummy variable takes the value I during September, October and November I9I 8 to account for the impact that news of the end of the war might have had on securities markets. On the one hand, the end of the war might have increased prices and reduced yields, since the need for further debt financing would be reduced. However, the Treasury reports that security sales were heavy at the end of the war: 'Many of these sales were the result of conditions produced by the ending of the war' (Secretary of the Treasury I920b, p. 82). These sales by the public required that the WFC make sizable purchases at that time to stabilize markets.

\section{VII}

Analysis of WFC purchases focuses on the Third and Fourth Liberty bond issues. The WFC purchased the largest dollar amounts of these two issues, over \$500 million each. The purchases of either the Third or Fourth Liberty bonds exceeded the purchases of the other five issues combined. While results for all issues are discussed, figures are reported for only the Third and Fourth issues. ${ }^{36}$

I9I9, necessitating computing a comparable data series beginning in December I9I7, when the estimates begin.

34 'Call money rate hits 25 per cent', New York Times, 30 December 1919, p. 20. Meltzer (2003, p. I04) discusses the Fed's falling reserve position.

35 Contemporary accounts also considered the call loan rate to be the 'money market' rate of interest (New York Times, I7 June I9I9, p. 29).

36 Tables and figures for the other issues are available from the authors upon request. We estimated BSVAR models for the rest of the issues using commercial paper rates, current war bond yields, 
Median impulse response functions following a positive one standard error shock to WFC purchases and the New York Fed's discount rate are presented in Figures 4-7 for the Third and Fourth bonds, along with Bayesian shape 68 percent error bands around the mean response. ${ }^{37}$ Sims and Zha (1999) argue that their approximate one standard deviation (68 percent) error bands provide a better indication of the range of uncertainty than 95 percent confidence intervals. The error bands trace the general trend and shape of the response functions and the densities of the bands account for serial correlation in the responses (Sims and Zha I999; Brandt and Freeman 2006). The bands are not necessarily symmetrical, as is the case for some of the bands in Figures 4-7.

The main results show that positive one standard error shock to WFC purchases has a negative and statistically significant effect on war bond yields for both issues of war bonds. The results for the other five issues also indicate a statistically significant negative effect of WFC purchases on war security yields.

The responses of the call loan rate to WFC war bond purchases are positive and statistically significant for the Third issue between the first and the ninth week; responses to a shock following purchases of the Fourth Liberty bonds are positive and statistically significant for weeks four through six. Results for the issues not shown are mixed. For these other issues the call loan rate responds positively to a shock to WFC purchases, but the results are statistically significant only for Victory notes.

A positive shock to the New York Fed's discount rate has a statistically significant and negative effect on call loan rates for both the Third and the Fourth Liberty bonds. ${ }^{38}$ For the issues not shown, the effect of the discount rate on the call loan rate is positive and statistically significant for all issues, except the positive response for the First Liberty bond at 4.25 percent, which is not statistically significant. The discount rate shocks on war bond yields have negative and statistically significant results for the Fourth Liberty bonds and are not statistically significant for the Third Liberty bonds.

The dummy variable is statistically insignificant in both BSVARs. Any effect of the end of the war is likely to be reflected in the response to WFC purchases. As noted above, increased sales at the end of the war required increased WFC purchases to maintain price stability.

Both the Third and the Fourth war bond yields decreased following a positive shock to WFC purchases. These results indicate that the war bond purchase program implemented by WFC was successful in stabilizing war bond prices.

and WFC purchases. In addition, we estimated models for all the issues using commercial paper rates instead of call loan rates and current yields instead of yields to maturity. The results are consistent and very close in magnitude to the ones reported in the appendix.

37 Median responses are computed by cumulating the Markov Chain Monte Carlo samples point wise, and then reporting the median response and confidence intervals (Brandt and Freeman 2009).

38 Such anomalous responses are sometimes a by-product of structural VAR models. 



Figure 4. Third Liberty loan at 4.25 percent: positive shock to WFC purchases
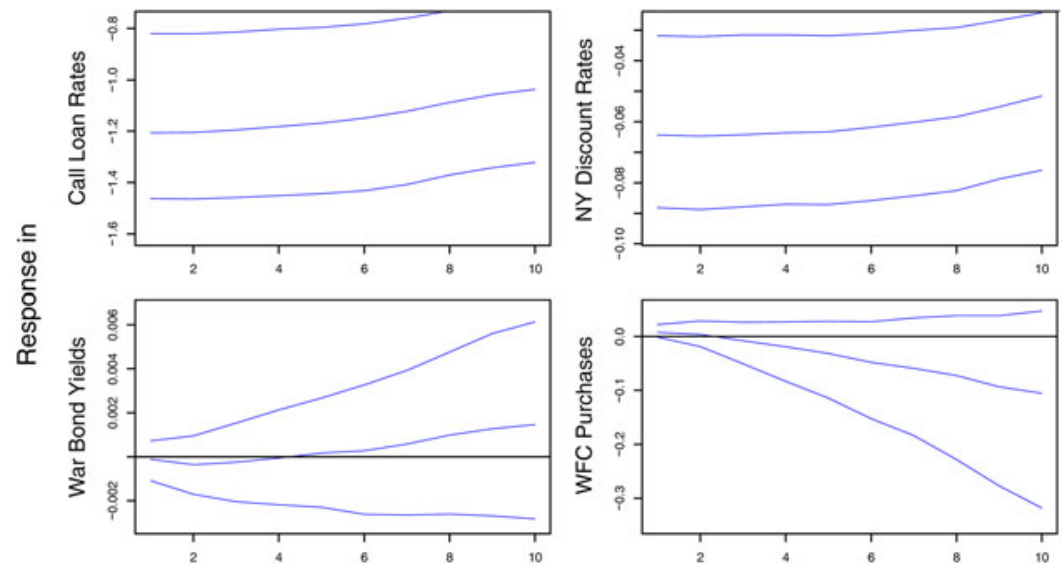

Figure 5. Third Liberty loan at 4.25 percent: positive shock to New York discount rates

Table 2 shows the impact (first period effect) of positive shocks to WFC purchases on war bond yields, measured in percentage points ( $\mathrm{I} . \mathrm{O}=\mathrm{I}$ percent).

On impact, as displayed in Table 3, an increase in WFC purchases causes both war bond yields to fall. The decrease is 7 basis points (bp) for the Third and 4 bp for Fourth Liberty bond. ${ }^{39}$ Over time, after about nine weeks following the shock, the effect dies

39 The effects of WFC purchases on war bond yields, while small, are statistically significant, and offset a trend of increasing interest rates over most of the sample. 

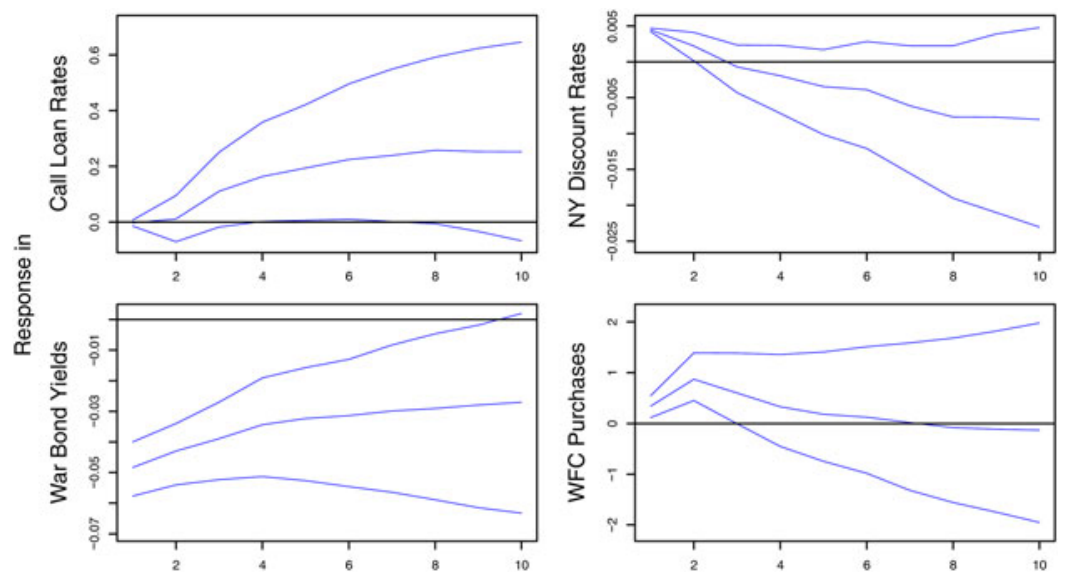

Figure 6. Fourth Liberty loan at 4.25 percent: positive shock to WFC purchases
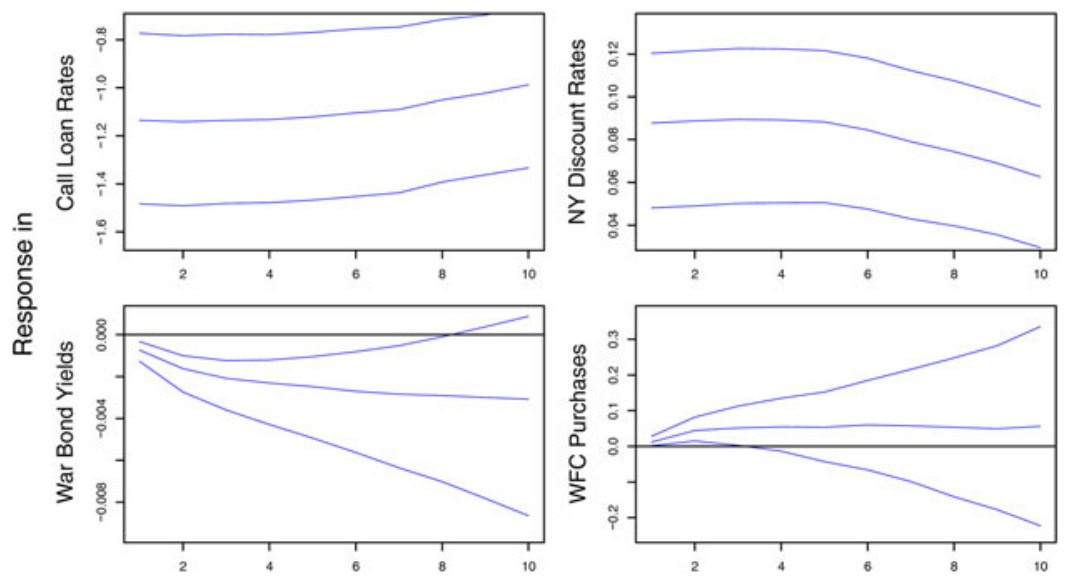

Figure 7. Fourth Liberty loan at 4.25 percent: positive shock to New York discount rates

out. Since the price effects of the bond purchases were transitory, the WFC would have had to make purchases continuously to maintain prices, a result consistent with the facts. While not specifically tested, the growth in outstanding federal debt from 2.67 percent of GDP to 33.5 percent of GDP from December I9I6 to December I9I9 most likely put upward pressure on war security yields, necessitating continued purchases to stabilize prices.

While WFC purchases had a small impact on war bond yields, they did succeed in keeping the yields below the 5.5 percent psychological threshold and a weekly bond price above 90 points. Figures $2-3$ above and Figures $8-9$ show war bond yields rising 
Table 3. Time profiles of median responses in war bond yields to a positive shock to WFC purchases $(1.0=1 \%)$

\begin{tabular}{|c|c|c|c|c|c|c|c|c|c|c|}
\hline Liberty bonds/weeks & I & 2 & 3 & 4 & 5 & 6 & 7 & 8 & 9 & IO \\
\hline Third $4.25 \%$ & $-0.07 \mathrm{I}$ & $-0.05 \mathrm{I}$ & -0.034 & -0.023 & -о.ог6 & -O.OII & -0.007 & -0.003 & o & 0.002 \\
\hline Fourth $4.25 \%$ & -0.04 & -0.034 & -0.027 & -0.019 & -0.0I6 & -0.013 & -0.008 & -0.005 & -0.002 & 0.002 \\
\hline
\end{tabular}




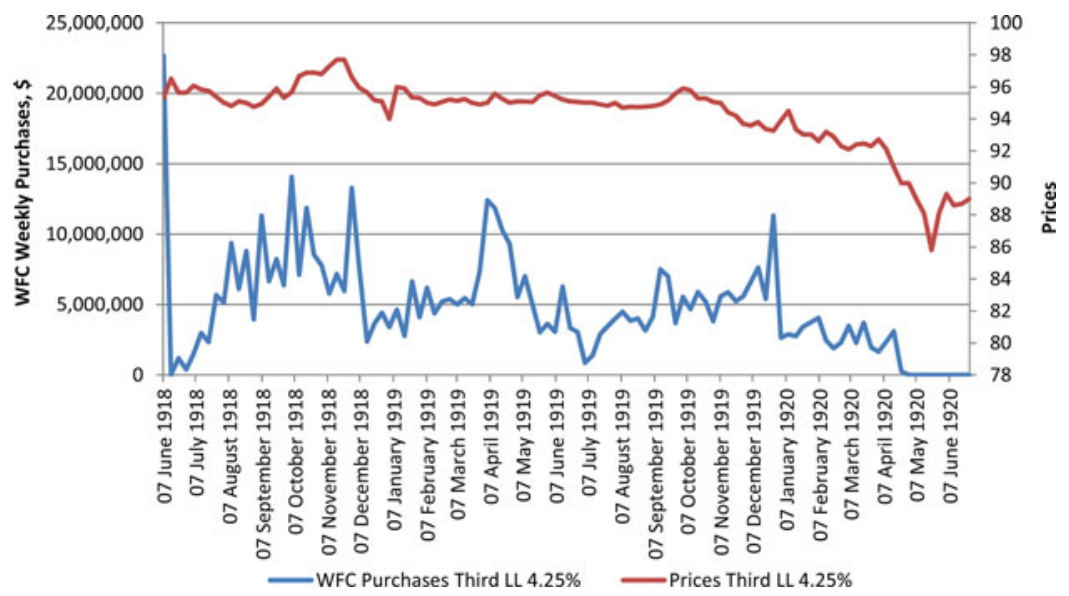

Figure 8. Third Liberty loan 4.25 percent: WFC weekly purchases and prices

Source: National Archives Record Association II. Record Group I 54. Commercial and Financial Chronicle, weekly issues, June I9I7 - June I920

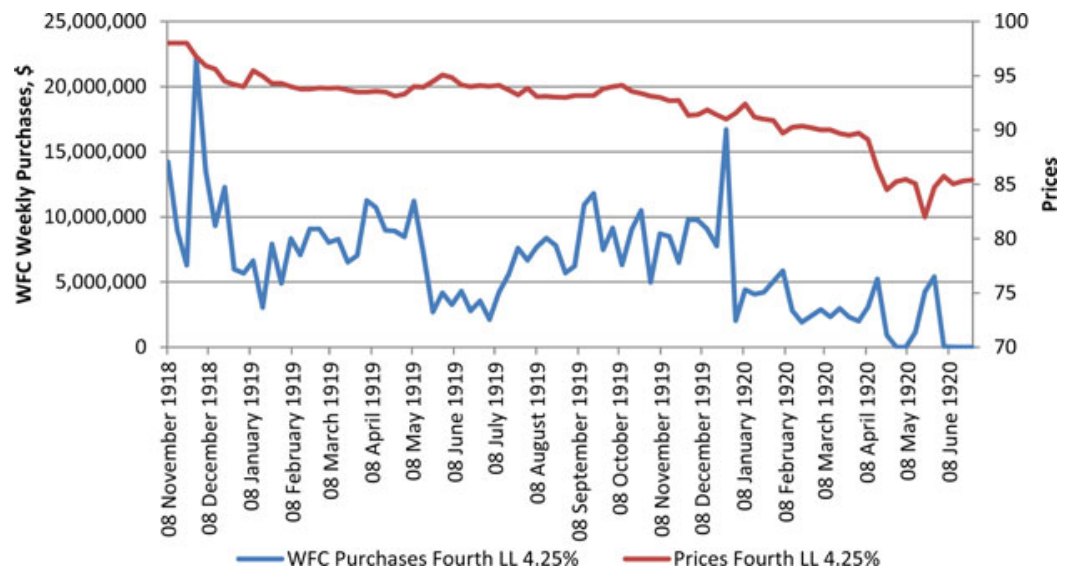

Figure 9. Fourth Liberty loan at 4.25 percent: WFC weekly purchases and prices

Source: National Archives Record Association II. Record Group I 54. Commercial and Financial Chronicle, weekly issues, November I9I 8 - November 1920

above 5.5 percent and bond prices dropping below 90 points respectively, coinciding with the end of WFC purchases.

A one standard deviation shock to WFC purchases translates into purchases of approximately \$0.7 million for the Third Liberty Bond and \$2 million for the Fourth Liberty Bond. For the fourth Liberty bond, an impact of 4 bp induced by WFC purchases represents about II percent of the standard deviation of the 
corresponding yield to maturity, computed during the WFC purchases period. During this period, one standard deviation in the fourth Liberty bond yields was equivalent to $35 \mathrm{bp}$.

The corresponding impact of $7 \mathrm{bp}$ on the third Liberty bond represents $\mathrm{I} 2$ percent of the standard deviation of war bond yields. One standard deviation in the third Liberty bond yields was equivalent to $55 \mathrm{bp}$. Thus, a significant change in war bond yields, of about one standard deviation from the mean for each bond (during period coinciding with WFC purchases), would have been achieved by WFC purchases larger by a magnitude of 9 .

WFC purchases of the Third and Fourth bonds have a positive and statistically significant effect on call loan rates, as shown by the impulse response functions displayed in Figures 4 and 6. As discussed above, war bonds were subsequently sold to the Treasury. Between issues of the Liberty securities, the Treasury financed its operations by sales of Certificates of Indebtedness. The actual or expected increase in the supply of short-term Certificates of Indebtedness by the Treasury to repurchase securities from the WFC appears to have decreased prices and therefore drove up short-term yields, while purchases by WFC of war bonds decreased long-term yields. Therefore, the positive effect on the call loan rate along with the negative effects on war bond yields indicates a twisting of the yield curve. ${ }^{40}$

It is useful to compare the results of the WFC security purchases with Operation Twist and the recent Quantitative Easing programs. One important difference is that these latter programs included open market operations. The Fed's holdings of government securities increased on net by $\$$ I.4 billion during Operation Twist (Swanson 20II, p. I55 and n. 9). The several rounds of Quantitative Easing have expanded the monetary base from less than $\$ 900$ billion to $\$ 4$ trillion. In contrast, the WFC purchases were on net a maturity swap; there was no net monetary expansion resulting from the WFCs security purchases.

The WFC purchases of \$I.4 billion were I.8 percent of I9I9 GNP. Since the purchases were spread over approximately 23 months, annual purchases were about 0.9 percent of GNP. Comparably, Operation Twist in I96I of $\$ 8.8$ billion was I.7 percent of GDP, ${ }^{41}$ while the Fed's 2 OII-I 2 program of $\$ 667$ billion is 4.4 percent of 20 I I GDP, or 3.4 percent on an annualized basis. Then in January 2013 the Fed announced that its combined purchases of longer-term Treasury securities and mortgage-backed securities would total $\$ 85$ billion per month, or approximately 6.I percent of annualized GDP. ${ }^{42}$ The WFC purchases that had a small but statistically significant impact on yields were smaller on an annualized basis than the I96 I program

40 Results of a robustness check using an alternative discount rate are reported in Appendix II.

41 Swanson (20 I I, n. 9) reports that the Fed purchased $\$ 8.8$ billion of long-term Treasuries but reduced holding of bills by $\$ 7.4$ billion.

42 GDP data are from the Bureau of Economic Analysis. Data for the I96 I program are from Swanson (2OI I, p. I 55 and n. 9) and for the 20 I I-I 2 and 2013 programs from Board of Governors of the Federal Reserve System (2013). 
that has been estimated to reduce Treasury bond yields by I 5 basis points. ${ }^{43}$ The Fed's recent program is substantially larger. On 22 May 20I3, the chairman, Ben Bernanke, announced that the Fed was considering scaling back its bond purchases. From $2 \mathrm{I}$ May through 22 August, the Io-year Treasury bond yield increased by 96 basis points, indicating that the recent program has had a substantial effect, although it is too soon to conduct a formal analysis of the current program. ${ }^{44}$

As is evident in Figures 2 and 3 above, at the time of the announcement of the end of the WFC's war bond purchases, yields increased considerably. The trend line suggests a structural break at the time the end of the bond purchase program was announced. ${ }^{45}$ The trend break may be due to the fact that the program was effective. It may also reflect a change in expectations about future prices and yields, that upon completion of the sale of the final Victory notes, the Treasury had no incentive nor interest in stabilizing the prices of its bonds. ${ }^{46}$ Furthermore, Figures 8 and 9 show WFC purchases of third and fourth Liberty bonds and corresponding weekly bond prices. The end of the WFC purchase program coincided with the drop in war bond prices below the 90 points threshold, which in this case may be interpreted as a psychological red line.

\section{VIII}

The WFC was created in I9I 8 to exert some influence on capital markets and to insure adequate funding for businesses deemed essential to the war effort. These activities of the WFC were relatively limited. ${ }^{47}$

As the war required the Treasury to issue securities in heretofore unimagined amounts, the Treasury had an incentive to stabilize prices to make the securities attractive to purchasers. The general public was urged to purchase securities as an act of patriotism, and war securities were issued in small as well as large denominations to make them attractive to citizens with limited financial wealth. However, after issue, the war securities traded at discounts from par value, much to the dismay of many citizens who had purchased them. To placate the public, and to facilitate future security issues, the Treasury had an incentive to stabilize security prices.

The Third Liberty Bond Act authorized the Treasury to repurchase up to 5 percent of the outstanding issues annually in order to stabilize bond prices. This Act was passed

43 Swanson (20 I I) estimates that this was the effect of Operation Twist on Treasury bond yields.

44 Data for the Treasury bond yield are from Federal Reserve Bank of St Louis - FRED: http://research. stlouisfed.org/fred2/graph/?id=DGS10.

45 'Treasury to stop buying of bonds', New York Times, i 8 April I920, p. I5.

46 Sims (I980) proposed to model economic expectations with VAR models. The expectations are expressed through the dynamic behavior of the model, or via the impulse response functions. These are referred to as 'VAR expectations'.

47 Other than the war security purchases, the most significant activity of the WFC was its lending to banks in an effort to relieve agricultural distress during the period I92I-4 (Secretary of the Treasury 1943). 
at the same time the WFC legislation was approved, and the Treasury delegated the repurchase of war bonds to the WFC.

During a two-year period, the WFC purchased almost \$I.5 billion of bonds at market prices that it sold to the Treasury. While the Third Liberty Bond Act had authorized the creation of a sinking fund from unappropriated funds, there were during this period no unappropriated funds, as there was a sizable budget deficit. Between its sales of Liberty and Victory securities, the Treasury issued short-term debt to fund its expenditures net of taxes.

This article reports the results of an analysis of the WFC's security purchases, to assess the impact on both short-term and long-term yields. Bayesian structural vector autoregression models are estimated for each war security issue. The results indicate a statistically significant, albeit economically small, negative impact of WFC purchases on war security yields for all issues purchased.

The results also indicate, for those bond issues purchased in greatest quantities, that the purchases had a statistically significant positive impact on the short-term interest rate. Thus, however inadvertently, the WFC purchases of war bonds twisted the yield curve.

Submitted: 6 March 2015

Revised version submitted: 3 I December 20 I 5

Accepted: 20 February 2016

\section{Sources}

BLAKE, N. and GORDON, J. (I989). The estimation of prewar gross national product: methodology and evidence. Journal of Political Economy, 97(I): 38-92.

Board of Governors of the Federal Reserve System. I943. Banking and Monetary Statistics. Washington, DC.

Board of Governors of the Federal Reserve System. 2013. www.federalreserve.gov/monetarypolicy/ maturityextensionprogram.faqs.

Bureau of Economic Analysis. www.bea.gov/iTable/iTable.cfm?ReqID=9\&step=1.

Bureau of Labor Statistics. ftp://ftp.bls.gov/pub/special.requests/cpi/cpiai.txt.

Commercial and Financial Chronicle. Weekly issues, June I9I7 - December I920.

Federal Reserve Bank of New York. I9I9. Fourth Annual Report.

Federal Reserve Bank of New York. I920. Fifth Annual Report.

Federal Reserve Bank of New York. I92 I. Sixth Annual Report.

Federal Reserve Bank of St Louis. FRED.

LEFFINGWELL, R. (I96I). Papers. Library of Congress.

MEYER, E. (I974). Papers. Library of Congress.

New York Times. Monday issues, 8 October I9I7-3 January I92 I; various issues I9I 8-20.

Secretary of the Treasury. I9I9. Annual Report, 1918. Washington, DC: United States Government Printing Office

Secretary of the Treasury. I920a. Letter From the Secretary of the Treasury. House of Representatives, document no. 905. Washington, DC: United States Government Printing Office

Secretary of the Treasury. I920b. Annual Report, 1919. Washington, DC: United States Government Printing Office

Secretary of the Treasury. I943. Liquidation of the War Finance Corporation. Washington, DC: United States Government Printing Office

War Finance Corporation. Records of the War Finance Corporation. National Archives Record Association II. Record Group I 54 


\section{References}

BERNANKE, B. (I986). Alternative explanations of the money-income correlation. Carnegie-Rochester Conference Series on Public Policy, 25, pp. 49-99.

BRANDT, P. and FREEMAN, J. (2006). Advances in Bayesian time series modeling and the study of politics: theory testing, forecasting, and policy analysis. Political Analysis, I4, pp. I-36.

BRANDT, P. and FREEMAN, J. (2009). Modeling macro-political dynamics. Political Analysis, I7, pp. I I $3-42$.

D'AMICO, S., ENGLISH, W., LOPEZ-SALIDO, D. and NELSON, E. (2O I2). The Federal Reserve's large-scale asset purchase programmes: rationale and effects. Economic Journal, I22, pp. 4I 5-46.

DOAN, T., LITTERMAN, R. and SIMS, C. (1984). Forecasting and conditional projection using realistic prior distributions. Econometric Reviews, 3, pp. I-IOO.

GAGNON, J., RASKIN, M., REMACHE, J. and SACK, B. (2OI I). Large-scale asset purchases by the Federal Reserve: did they work? Federal Reserve Bank of New York Economic Policy Review, 17, pp. $4 \mathrm{I}-59$.

GILBERT, C. (1970). American Financing of World War I. Westport, CT: Greenwood.

HAMILTON, J. (1994). Time Series Analysis. Princeton, NJ: Princeton University Press.

HOOGERHEIDE, L., VAN DIJK, H. and VAN OEST, R. (2009). Simulation-based Bayesian econometric inference: principles and some recent computational advances. In David A. Belsley and Erricos J. Kontoghiorghes (eds.), Handbook of Computational Econometrics. Chichester: Wiley.

KANG, S. and ROCKOFF, H. (2OI5). Capitalizing patriotism: the liberty loans of World War I. Financial History Review, 22, pp. 45-78.

LITTERMAN, R. (I986). Forecasting with Bayesian vector autoregressions five years of experience. Journal of Business, Economics and Statistics, 4, pp. 25-38.

MELTZER, A. (2003). A History of the Federal Reserve, vol. I. Chicago: University of Chicago Press.

MODIGLIANI, F. and SUTCH, R. (I966). Innovations in interest rate policy. American Economic Review, 56, pp. I78-97.

MODIGLIANI, F. and SUTCH, R. (1967). Debt management and the term structure of interest rates: an empirical analysis of recent experience. Journal of Political Economy, 75, pp. 569-95.

PUSEY, M. (1974). Eugene Meyer. New York: Alfred A. Knopf.

SIMS, C. (I980). Macroeconomics and reality. Econometrica, 48, pp. I-48.

SIMS, C. and ZHA, T. (I998). Bayesian methods for dynamic multivariate models. International Economic Review, 39, pp. 949-68.

SIMS, C. and ZHA, T. (I999). Error bands for impulse responses. Econometrica, 67, pp. I I I $3-56$.

SWANSON, E. (2O I I). Let's twist again: a high-frequency event-study analysis of operation twist and its implications for QE2. Brookings Papers on Economic Activity, Spring, pp. I 5 I-207.

VAYANOS, D. and VILA, J. (2009). A preferred-habitat model of the term structure of interest rates. National Bureau of Economic Research Working Paper no. I 5487, Cambridge, MA.

WAGGONER, D. and ZHA, T. (2003). A Gibbs sampler for structural vector autoregressions. Journal of Economic Dynamics \& Control, 28, pp. 349-66.

WILlOUGHBY, W. (1934). The Capital Issues Committee and War Finance Corporation. Baltimore: Johns Hopkins Press.

\section{APPENDIX I}

Doan, Litterman and Sims (1984), Litterman (1986) and Sims and Zha (1998) have demonstrated the usefulness of Bayesian inference techniques for macroeconomic modeling with vector autoregressions (Sims I980) and structural vector autoregressions (Bernanke I986) that make assumptions about contemporaneous relationships between variables. Bayesian inference involves the systematic incorporation of prior information into the modeling process while making probability statements about quantities of interest and testing the sensitivity of estimates (Hoogerheide, Van Dijk and Van Oest 2009). ${ }^{48}$

48 A typical Bayesian prior belief is that lag coefficients go to zero as lag length increases. 
A Bayesian structural vector autoregression (BSVAR) is constructed for each of seven war bonds as identified by its issue and its coupon rate of interest. For each type of bond, the following $\mathrm{m}$-dimensional SVAR model (in matrix notation) is constructed for a data sample of size $T$. The basic form of the model is the same as the model of Waggoner and Zha (2003): ${ }^{49}$

$$
y_{t} A_{\circ}=\sum_{l=\mathrm{I}}^{p} Y_{t-l} A_{l}+z_{t} D+\varepsilon_{t}, \quad t=\mathrm{I}, \ldots, T
$$

where $y_{t}$ is the vector of observations for $\mathrm{m}$ endogenous variables at time $\mathrm{t}, A_{\mathrm{o}}$ is the non-recursive contemporaneous coefficient matrix for the structural model, ${ }^{50} A_{l}$ is the coefficient matrix for the $l^{\text {th }}$ lag, with the maximum number of lags $p, D$ represents the vector of constant terms, and $\varepsilon_{\mathrm{t}}$ is the vector of i.i.d. structural shocks, assumed to be normal with mean and variance given by:

$$
\begin{aligned}
& E\left(\varepsilon_{t} \mid y_{\mathrm{I}, \ldots}, y_{t-\mathrm{I}}, z_{\mathrm{I}, \ldots,}, z_{t-\mathrm{I}}\right)=0 \\
& E\left(\varepsilon_{t} \varepsilon_{t}^{\prime} \mid y_{\mathrm{I}, \ldots,} y_{t-\mathrm{I}}, z_{\mathrm{I}, \ldots,}, z_{t-\mathrm{I}}\right)=I
\end{aligned}
$$

The reduced form version of the model is obtained by post-multiplying (I) by $A_{o}^{-1}$. Thus, the structural restrictions are incorporated in the residuals of the reduced form model as well as the dynamics of the system (Hamilton I994).

$$
y_{t} A_{\mathrm{o}} A_{\mathrm{\circ}}^{-\mathrm{I}}=\sum_{l=\mathrm{I}}^{p} Y_{t-l} A_{l} A_{\mathrm{o}}^{-\mathrm{I}}+z_{t} \mathrm{D} A_{\mathrm{o}}^{-\mathrm{I}}+\varepsilon_{t} A_{\mathrm{o}}^{-\mathrm{I}}
$$

with the reduced form error covariance matrix derived as:

$$
E\left[\left(\varepsilon_{t} A_{\circ}^{-\mathrm{I}}\right)^{\prime}\left(\varepsilon_{t} A_{\circ}^{-\mathrm{I}}\right)\right]=A_{\circ}^{-\mathrm{I} \prime} A_{\mathrm{o}}^{-\mathrm{I}}
$$

Model (I) is a dynamic simultaneous system of equations and thus the coefficients in the matrix $A_{l}$ describe the dynamic impact of the past values on the current values of each endogenous variable, while the coefficients in $A_{o}$ describe the impact at time 'o', or how the variables are interrelated to each other in each time period (each week). The structural parameters are identified by imposing non-recursive linear constraints on the contemporaneous matrix $A_{o}$ (zero restrictions correspond to a lack of contemporaneous feedback).

Bayesian estimation of model (I) requires the specification of a prior density that incorporates beliefs about the dynamic properties of the variables included in the model. This prior density is specified for the vectorized parameters in $A_{o}$ and $A_{l}$ as $a_{o}=\operatorname{vec}\left(A_{o}\right)$ and $b=\operatorname{vec}\left(B_{l}\right)$. Vectors $a_{\mathrm{o}}$ and $\mathrm{b}$ represent the columns of $A_{o}$ and $A_{l}$ respectively, stacked from left to right for each equation. The prior density function over $a_{\mathrm{o}}$ and $\mathrm{b}$ is given by:

$$
p(a)=p\left(a_{0}\right) \phi(\mu(b), \Sigma)
$$

where $\phi(.,$.$) is a multivariate normal density with mean \mu(b)$ and covariance matrix $\Sigma$; and $p\left(a_{0}\right)$ is $a_{o}$ 's marginal distribution. The multivariate reference prior for the parameters in model (I) is specified for $p\left(b \mid a_{\mathrm{o}}\right)$ by a set of hyperparameters, which incorporate substantial economic theory. For a detailed discussion about the choice of the parameter values entering the prior density (or the informative prior), see Litterman (I986), Sims and Zha (I998), Brandt and Freeman (2006, 2009). Therefore, using Bayes' rule, the posterior density for model (I) is obtained from the prior and the likelihood functions:

$$
p(A) \propto L(Y \mid A) p\left(a_{\circ}\right) \phi(\mu(b), \Sigma),
$$

49 A more detailed development of BSVARs is provided by Brandt and Freeman (2006).

50 The matrix $A_{o}$ is assumed to be nonsingular and identified (Sims and Zha I998). 
where $L(Y \mid A)$ is the likelihood function and $A$ represents the vectorized parameters:

$$
A=\left[\begin{array}{l}
A_{0} \\
B_{l}
\end{array}\right]
$$

The specification of the BSVAR models is done in two steps. First, the prior density parameters are specified for the reduced form model and second, the contemporaneous restrictions in the $A_{o}$ matrix are specified.

Table Aı. Sims-Zha prior density hyperparameters for the war bond models

\begin{tabular}{llllllllll}
\hline \hline Parameters & $\lambda_{\mathrm{O}}$ & $\lambda_{\mathrm{I}}$ & $\lambda_{2}$ & $\lambda_{3}$ & $\lambda_{4}$ & $\lambda_{5}$ & $\mu_{5}$ & $\mu_{6}$ & lags $(p)$ \\
\hline Values & 0.6 & o.I & I & I & o. I & I & 2 & 0 & 2 \\
Range & {$[\mathrm{O}, \mathrm{I}]$} & $>_{\mathrm{O}}$ & $\mathrm{I}_{\mathrm{I}}$ & $>_{\mathrm{O}}$ & $\geq_{\mathrm{O}}$ & $\geq 0$ & $\geq 0$ & $\geq 0$ & $\geq_{\mathrm{I}}$ \\
\hline \hline
\end{tabular}

\section{Prior density specifications}

Table A I reports the model specifications. For each of the seven war bond models, the prior density is specified using the Sims-Zha (1998) reference prior. The BSVAR models specified by (I) are estimated with the parameter values for the prior densities displayed in Table AI. The benchmark priors proposed by Sims and Zha (I998) are the values used for $\lambda_{\circ}-\lambda_{5}$ in Table AI. These six priors specify, respectively, overall tightness around the error covariance matrix, tightness around the variance of the AR(I) coefficients, the relative weight of each variable's own lags, the relative lag decay in the variance, tightness around the variance of the intercepts, and tightness around the coefficient of the exogenous dummy variables.

The parameters are modified for unit roots and common trends. Beliefs about unit roots are allowed, by setting $\mu_{5}=2$, however, due to the short time span of the data, the specification rules out a common stochastic trend, by setting $\mu_{6}=0$. The Sims-Zha (1998) prior improves upon the previously popular 'Minnesota prior' (Litterman I986) in that it is imposed on the entire system of equations, rather than equation-by-equation as was the case for the 'Minnesota prior'.

For all estimates, the Sims-Zha loose prior, described above, is tested against a tight prior $\left(\mu_{5}=5\right.$, $\left.\mu_{6}=5\right)$ using the log probability of the data (log marginal likelihood) to compare the prior specifications for the BSVAR models. The $\log$ marginal likelihood $(\log (m Y))$ is usually used to compare priors for BSVAR models (Brand and Freeman 2009, p. I32). A higher log marginal density estimate indicates a more likely posterior for the model, or a stronger preference for the model with the higher marginal density. For all the BSVAR models, a looser prior generated higher marginal log likelihoods, as compared to tighter prior specifications. ${ }^{51}$

\section{APPENDIX II: ROBUSTNESS CHECK}

We estimated our models for the third and fourth Liberty bond purchases using an alternative Federal Reserve discount rate. We substituted New York Fed's discount rates with i 5 -day loans secured by

51 Log marginal likelihood results are available from the authors upon request. 

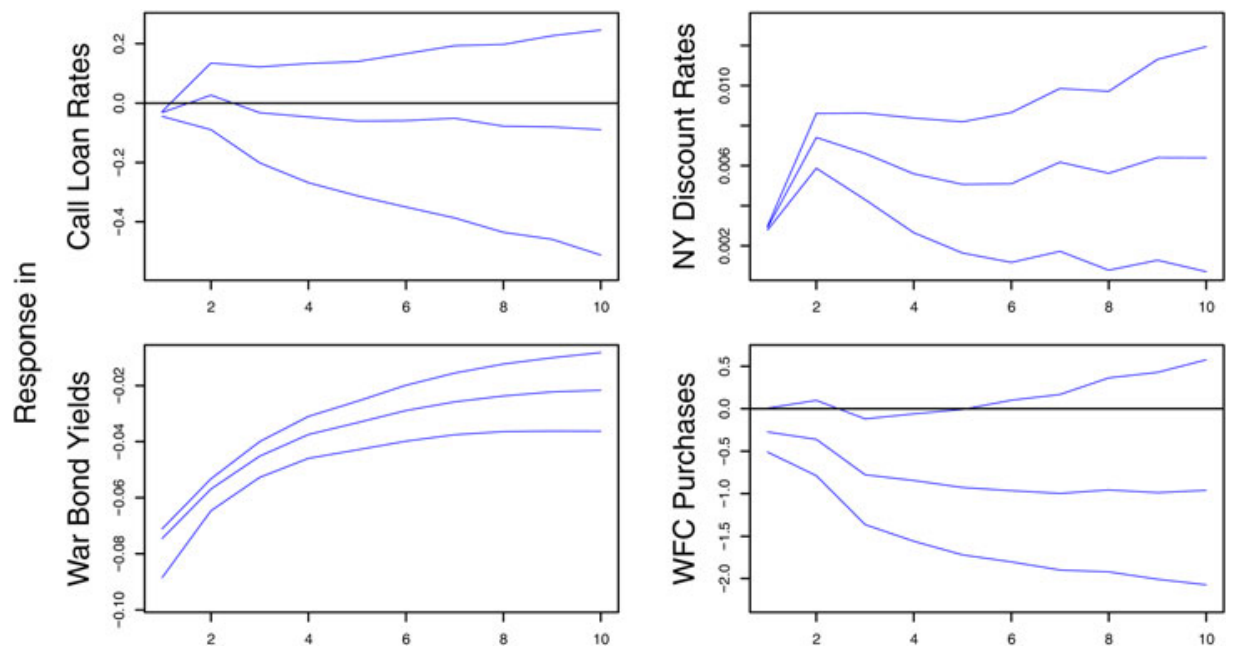

Figure A II.I. Third Liberty loan at 4.25 percent: positive shock to WFC purchases
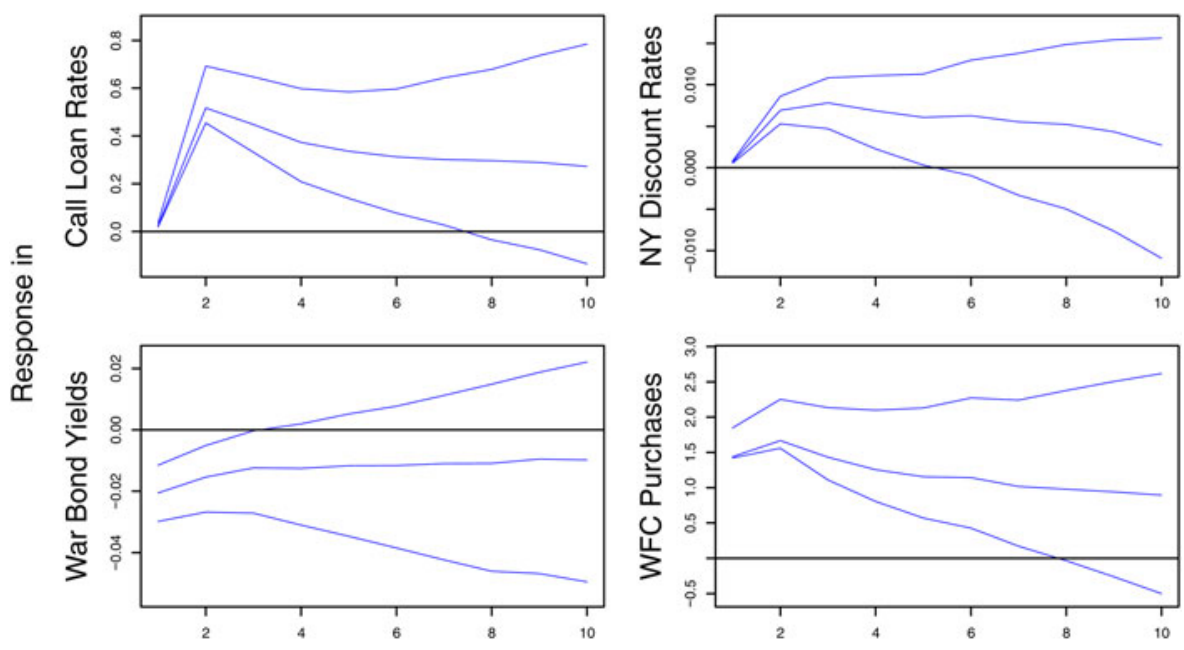

Figure A II.2. Fourth Liberty loan at 4.25 percent: positive shock to WFC purchases

certificates of indebtedness. ${ }^{52}$ The structure of the contemporaneous matrix of both models and the rest of the variables stayed the same.

The impulse-response functions based on models that include alternative Federal Reserve discount rates yield similar to the model in the paper for WRC bond purchases. Purchases of the third LL bonds have a significant effect of $7 \mathrm{bps}$, while purchases of the fourth LL bonds have an impact of

52 Federal Reserve Bank of New York (1919, I920, I92 I). 
3 bp that becomes statistically insignificant after the third week. WFC purchases of the fourth LL bonds have a negative and statistically significant effect on call loan rates. The response of the call loan rate to purchases of the third LL bonds is statistically insignificant. Additional results are available from the authors upon request. 